\title{
Menumbuhkan Minat pada Kain Nusantara Melalui Pelatihan Pembuatan Kain Ikat Celup (Jumputan) pada Warga Masyarakat
}

\author{
Mahendra Wardhana \\ Jurusan Desain Interior, Institut Teknologi Sepuluh Nopember, Surabaya, Indonesia \\ mahendra@interior.its.ac.id
}

\begin{abstract}
ABSTRAK
Batik sebagai salah satu produk kain nusantara merupakan salah satu warisan dari leluhur bangsa Indonesia yang telah dikenal luas di dunia. Sebagai peninggalan bersejarah yang hingga saat ini tetap dikagumi seluruh lapisan masyarakat, maka potensi batik dapat dipakai untuk mencapai kesempatan terbaik dalam menumbuhkan minat terhadap kain nusantara. Salah satu kain nusantara yang juga strategis untuk dikembangkan adalah kain jumputan. Karena lebih mudah dan cepat pembuatannya dari pada batik, kain jumputan akan mudah dipelajari oleh masyarakat. Melalui pelatihan pendampingan akan menjadi salah satu metode penumbuhan minat masyarakat dalam mengenal dan mengembangkan potensi kain nusantara. Hasil pendampingan tersebut menunjukkan bahwa minat kepada batik jumputan tersebut paling menonjol adalah dari motif yang dihasilkannya. Berbagai motif dapat dihasilkan dengan beberapa teknik pembuatan yang relatif mudah dikuasai peserta pelatihan. Sebagai hasil akhir dari upaya ini adalah masyarakat yang semula belum mengenal metode pembuatan kainjumputan ini, hanya dalam waktu dua jam masyarakat dapat menguasai dengan baik dalam menghasilkan berbagai motif kain jumputan.
\end{abstract}

Kata kunci: batik, kain nusantara, jumputan, pelatihan

ABSTACT

As one of the products of nusantara fabric, batikis the ancestral heritage of Indonesia that has been widely known in the world. As a historical heritage to this day still admired by the whole society, then this potential can be used to achieve the best opportunity in growing interest in the nusantara fabric. One of nusantara fabric is also positioned to be developed is jumputan. Because it is easier and faster than making batik, jumputan be easily learned by the community. Methods of training through mentoring will be one of the methods of growing interest. The results showed that the assistance to the interests of the most prominent jumputan motif is that it generates. Various motifs can be produced with some relatively simple manufacturing techniques mastered trainees. As the end result of this effort is the people who originally are not familiar with this method of making jumputan, in just over two hours the community can be controlled well in producing various jumputan motifs.

Keywords: batik, nusantara fabric, jumputan, training

\section{PENDAHULUAN}

Upaya pengembangan kain nusantara sebagai bentuk pelestarian budaya di masyarakat memerlukan berbagai upaya dan metode. Salah satu upaya yang dapat dilakukan adalah mengadakan pelatihan teknik pembuatan kain nusantara kepada masyarakat, karena dalam pembuatannya diperlukan pengetahuan teknik dan keuletan tersendiri. Misalnya dalam pembuatan kain batik sebagai salah satu kain nusantara membutuhkan konsentrasi serta serangkaian kegiatan yang saling berhubungan. Guna menumbuhkan minat masyarakat pada kain nusantara namun dengan tidak mengedepankan berbagai kesulitan yang ada, maka perlu 
kiranya untuk digunakan metode yang lebih menyenangkan, teknik yang mudah dan memiliki waktu produksi yang singkat (cepat). Jika dibandingkan dengan batik, proses pembuatan kain nusantara yang cepat dan mudah adalah kain jumputan.

Teknik pembuatan kain jumputan memiliki keunggulan dalam hal kekhasan hasil motif yang cenderung geometris dan memiliki waktu pembuatan yang relatif cepat. Proses membuat kain inilebih cepat dari pembuatan batik karena beberapa teknik batik seperti menutup kain dengan malam (lilin) tidak dilakukan. Proses menutup kain dengan malam ini pada kegiatan membatik membutuhkan ketekunan tersendiri. Hal ini akan berakibat pada bagian pewarnaan dan motif yang dihasilkannya. Namun pada kain jumputan pewarnaan dihasilkan dari teknik jumput dan ikat yang dapat menghasilkan jenis motif dan warna pada kain tersebut.

Dengan demikian pelatihan ini akan memiliki keungulan untuk menjadi teknik tersendiri yang menyenangkan. Proses mewarnai kain juga seperti dengan mencelupkan saja sehingga sangat sederhana. Proses ini akan menjadi sangat menarik juga dikarenakan peserta pelatihan akan dapat melakukannya sendiri sesuai eksperimen yang diinginkannya.

\section{METODOLOGI}

Teknik jumputan ini dapat dilaksanakan menjadi beberapa bagian kegiatan diantaranya adalah mempersiapkan bahan dan peralatan, merencanakan pola motif, dan pewarnaan. Kegiatan tersebut dapat diuraikan dengan keterangan perbagiannya sebagai berikut:

Tabel 1. Pembagian Kegiatan Pembuatan Kain Jumputan.

\begin{tabular}{|c|c|c|}
\hline No & Kegiatan & Keterangan Detail Kegiatan \\
\hline 1 & $\begin{array}{l}\text { Mempersiapkan bahan } \\
\text { batik }\end{array}$ & $\begin{array}{l}\text { Bahan terdiri dari: } \\
\text { - } \quad \text { Kain } \\
\text { - } \quad \text { Pewarna batik } \\
\text { - } \quad \text { Penguat warna batik } \\
\text { - } \quad \text { Barang lain yang digunakan untuk membentuk pola (seperti kelereng } \\
\quad \text { untuk bentuk bulat, dll) }\end{array}$ \\
\hline 2 & $\begin{array}{l}\text { Merencanakan pola dan } \\
\text { hasil motif batik }\end{array}$ & $\begin{array}{l}\text { Dilaksanakan dengan teknik : } \\
\text { - } \quad \text { Melipat kain } \\
\text { - } \quad \text { Membentuk dan memasukkan barang kedalam kain untuk } \\
\quad \text { memperoleh pola }\end{array}$ \\
\hline 3 & $\begin{array}{l}\text { Merencanakan } \\
\text { pewarnaan }\end{array}$ & $\begin{array}{l}\text { Dilaksanakan dengan : } \\
\text { - } \quad \text { Memberikan warna di bagian tepi pola } \\
\text { - } \quad \text { Memberikan warna pada dasar kain }\end{array}$ \\
\hline
\end{tabular}

Selanjutnya kegiatan ini menjadi sangat baik bila dilaksanakan dengan perencaaan dan urutan yang bertahap. Rencana hasil dan teknik pembuatan polanya harus menjadi dasar bagi penentuan hasil pembuatan kain jumputan.

\section{PEMBAHASAN}

Teknik jumputan adalah teknik yang dicapai dengan cara mencelupkan kain pada warna sesuai pola yang telah dibentuk pada kain. Menurut Karmila, 2010 teknik ini sama dengan teknik ikat celup atau tie dye. Teknik ini menurutnya telah digunakan selama berabad-abad. Teknik jumputan ini sangat mengandalkan pola yang dihasilkan pada kainnya. Pola tersebut sesuai dengan pendapat Ustazah (2010) dan Ernawati (2009) yang membagi patra motif batik menjadi 3. Patra inilah yang membuat ciri motif kain menjadi kuat. 


\section{A. Teknik Batik Jumputan}

Beberapa teknik dalam batik jumputan antara lain:

\section{Teknik Pinching}

Teknik batik jumputan dengan menghias kain dengan cara mengambil bagian kain dengan mencubitnya ('men-jumput') dan mengikatnya jumputan tersebut dengan tali. Teknik inilah yang menyebabkan teknik ini disebut dengan batik 'jumputan'.

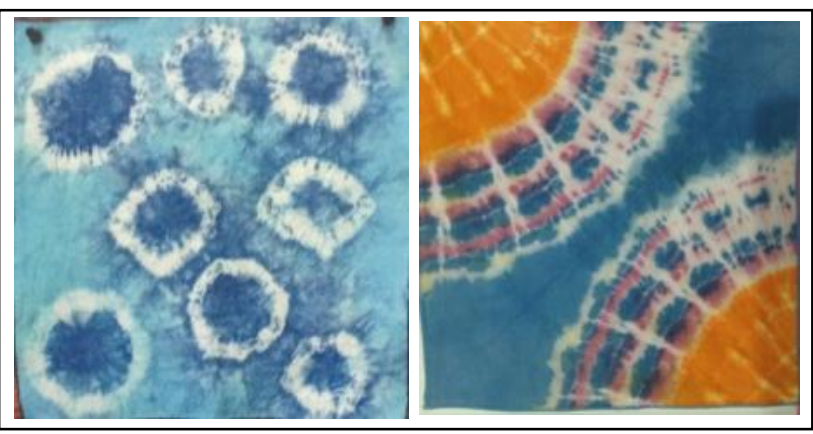

a. b

Gambar 1. Hasil Kain Ikat Celup dengan Teknik Pinching (a. Karya Hana Lamria (2015), b. Karya Dinda Ayu Puspita) Sumber : Dokumentasi Anggri Indraprasti (2015)

\section{Teknik Ombre}

Teknik menghias kain yang memanfaatkan lama dan cepatnya waktu pewarnaan dengan cara pencelupan dan (rembesan) warna ke dalam pewarna. Teknik ini akan menghasilkan gradasi warna pada kain batiknya.

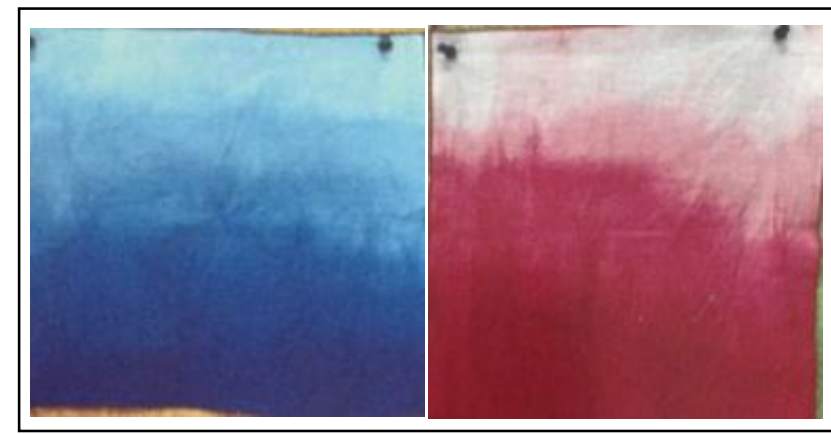

Gambar 2. Hasil Kain Ikat Celup dengan Teknik Ombre Karya Hana Lamria. Sumber : Dokumentasi Anggri Indraprasti (2015)

\section{Teknik Shibori}

Teknik menghias kain dengan melipat-lipat kain, sehingga kain yang terlipat akan membentuk pola dalam pewarnaannya. Kain terlipat akan dapat membentuk pola geometris dengan warna pada tepi lipatnya. 
Mahendra Wardhana

Menumbuhkan Minat pada Kain Nusantara Melalui Pelatihan Pembuatan Kain Ikat Celup (Jumputan) pada Warga Masyarakat

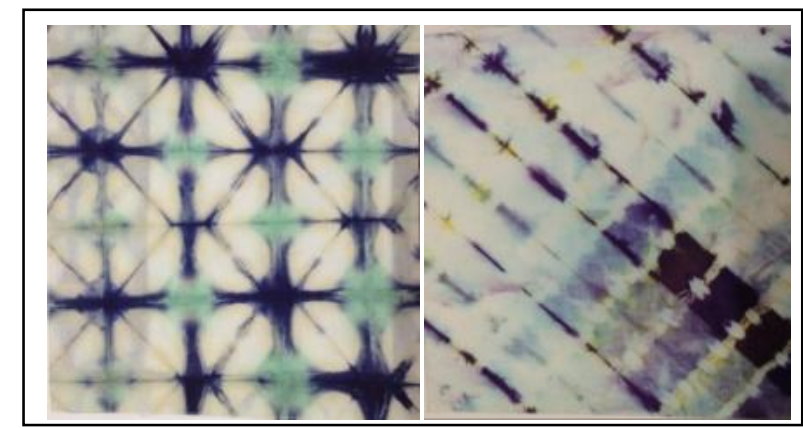

Gambar 3. Hasil Kain Ikat Celup dengan Teknik Shibori Karya Dewi Sitha.

Sumber : Dokumentasi Anggri Indraprasti (2015)

4. Teknik Pole

Teknik menghias kain dengan menggulung kain dengan bantuan benda lain, yang kemudian ditali. Setelah diberikan warna, maka efek tali tersebut akan terlihat pada kain batiknya.

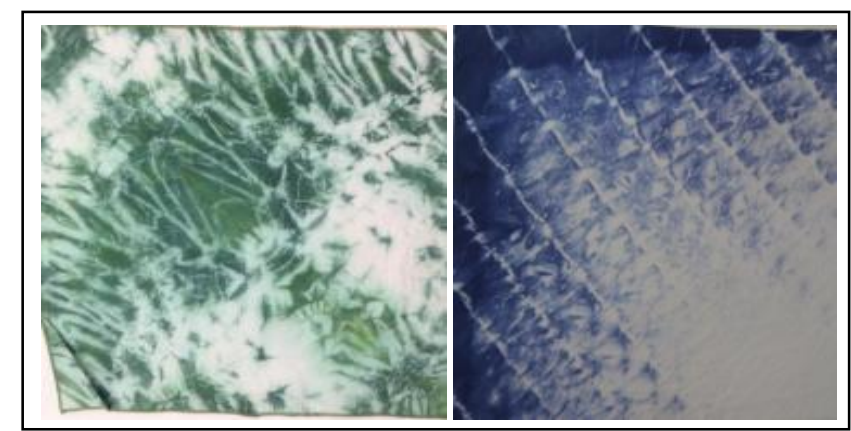

Gambar 4. Hasil Kain Ikat Celup dengan Teknik Pole Karya Hana Lamria dan Maharani Versyah Sumber : Dokumentasi Anggri Indraprasti (2015)

5. Teknik Kombinasi

Teknik menghias kain ikat celup dengan menggunakan gabungan berbagai kombinasi yang ada pada kain batinya.

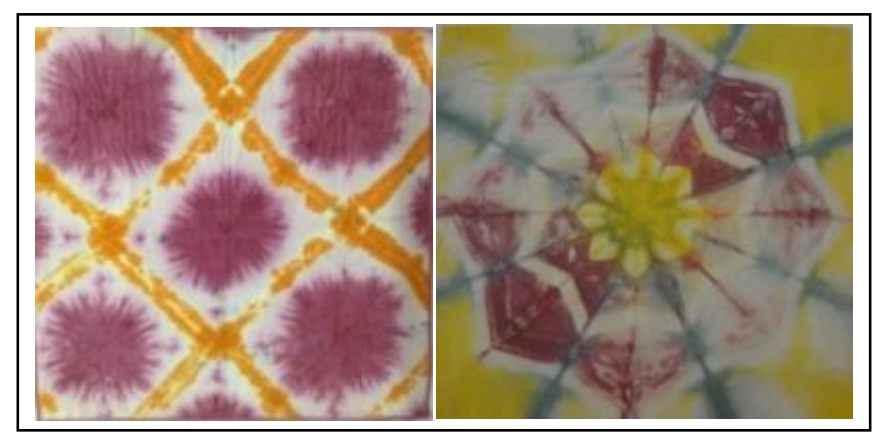

Gambar 5. Hasil Kain dengan Teknik Kombinasi (shibori \& Jumput) Karya Dinda Ayu P. dan Riza Nurmalita Sumber : Dokumentasi Anggri Indraprasti (2015)

\section{B. Proses Pendampingan Dalam Pembuatan Batik Jumputan}

Pendampingan dilaksanakan dengan pola workshop pendampingan satu kelompok dengan satu pendamping. Satu kelompok berisi setidaknya 5 sampai 6 orang. Satu kelompok bebas menggunakan teknik dalam batik jumputan. Hasil dari pelatihan ini adalah seperti di bawah ini. 
1. Mendalami Teori Batik Jumputan

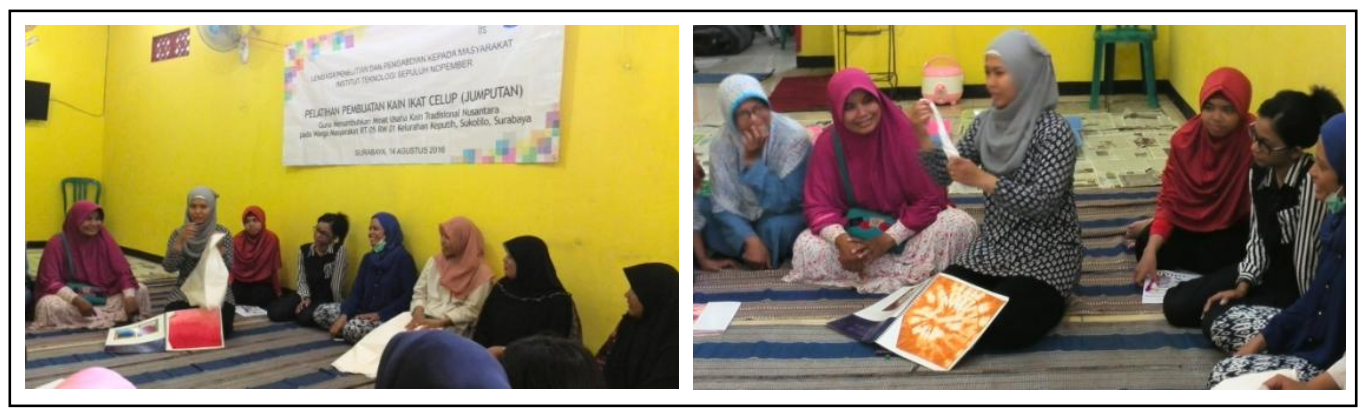

Gambar 6.Penjelasan Teknik Pembuatan Kain Jumputan. Sumber : Dokumentasi Penulis (2016)

2. Mendalami Teknik, Proses dan Cara Membentuk Pola

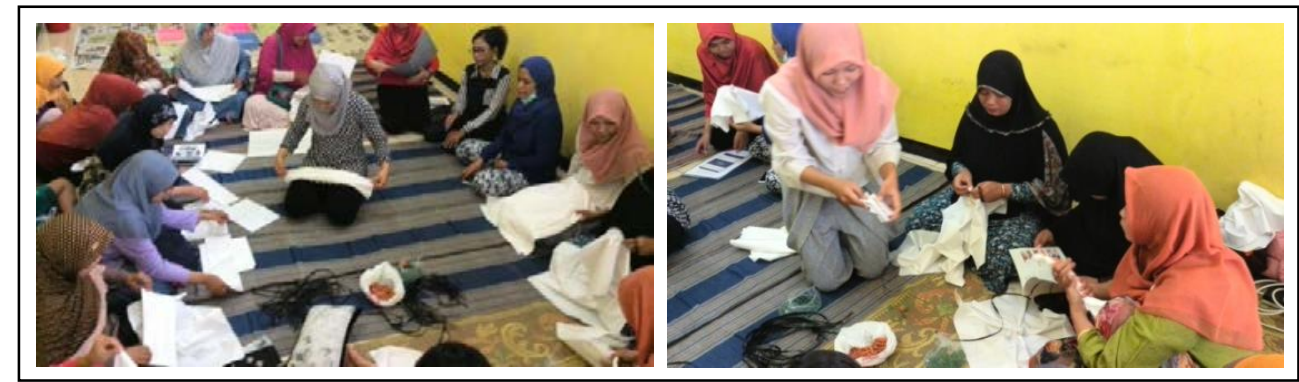

Gambar 7. Proses Pembuatan Pola Jumputan di Kain Batik dengan Melipat Kain dan Mengikat. Sumber : Dokumentasi Penulis (2016)

3. Proses Pendampingan Selama Pelatihan

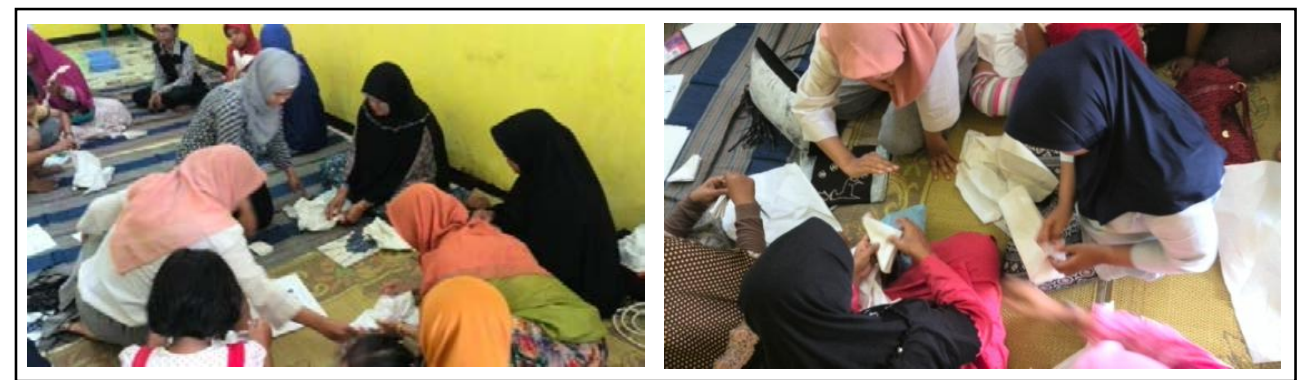

Gambar 8.Proses Pendampingan Kepada Peserta Sumber : Dokumentasi Penulis (2016)

4. Pewarnaan

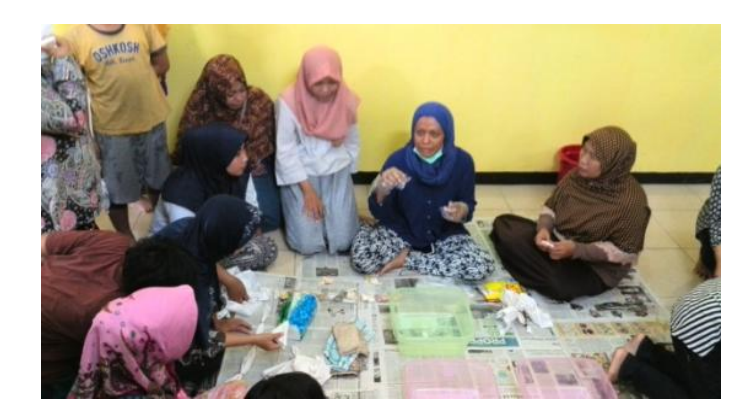

Gambar 9.Penjelasan Teknik Pewarnaan Kain Batik Sumber : Dokumentasi Penulis (2016) 


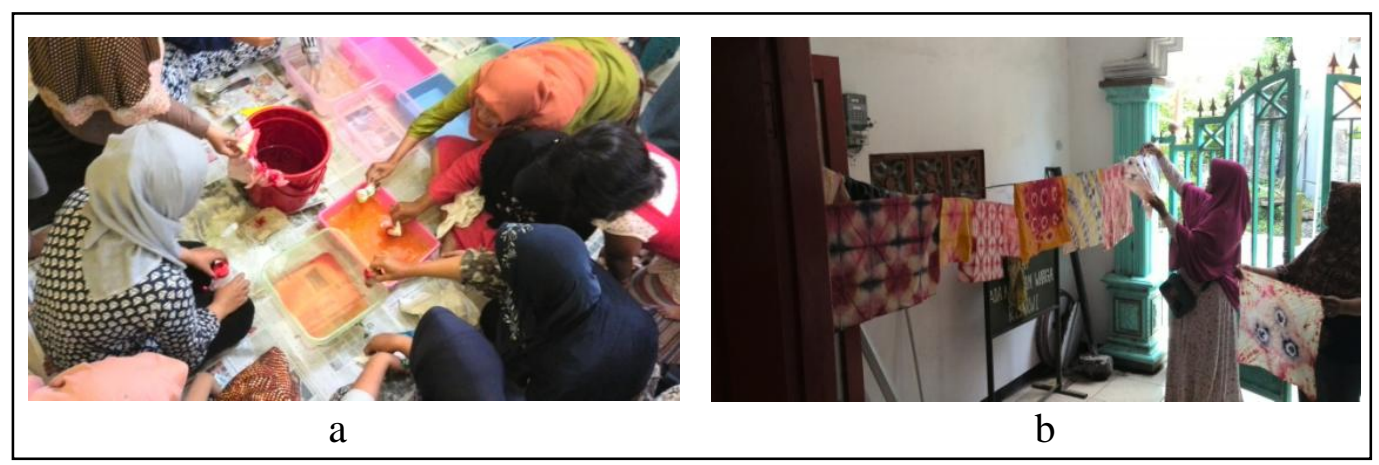

Gambar 10. (a) Proses Pewarnaan, (b) Proses Penjemuran Sumber : Dokumentasi Penulis (2016)

Seperti kain batik, salah satu kekuatan pada kain jumputan ini adalah karena pewarnaan dan motifnya. Ini adalah guna memperkuat dari pendapat dari Dharsono (2007) dan Tirta (2009) yang menyebutkan bahwa kekauatan batik klasik adalah pada pewarnaannya.

Dengan proses pelatihan ini maka semua peserta telah berhasil dalam membuat kain jumputan dengan berbagai teknik. Salah satu manfaat lain dari pelatihan ini adalah minat kepada kain nusantara telah tumbuh dilihat dari antusias peserta yang tetap mengikuti pelatihan dari awal hingga akhir selesainya pelatihan.

\section{KESIMPULAN}

Dengan pelatihan melalui metode bertahap, maka seluruh peserta pelatihan dapat menguasai materi kain jumputan dengan baik. Hal ini ditunjukkan dengan hasil kain jumputan peserta yang beraneka ragam motifnya. Hasil akhir kain jumputan ini diharapkan akan dapat menumbuhkan minat pada kain nusantara secara umum dan kain jumputan pada khususnya. Kegiatan ini dilaksanakan dengan menggunakan metode:
1. Penjelasan
2. Perencaaan
3. Pelaksanaan
4. Pola pendampingan

Kegiatan seperti ini tentunya tidak akan menghasilkan manfaat yang optimal apabila tidak didukung oleh kesiapan materi yang cukup. Dengan demikian kunci penting dalam pelatihan ini adalah kerena persiapan materi yang memadai dan lengkap dari pemateri.

\section{PUSTAKA}

Dharsono.(2007). Budaya Nusantara. Bandung : Penerbit Rekayasa Sains.

Ernawati. (2009). Seni Batik Mojokerto. Retrieved from :www.batikmojokerto.blogspot.com Kamila, Mila. (2010). Ragam Kain Tradisional Nusantara (Makna, Simbol dan Fungsi). Depok : Bee Media Indonesia.

Tirta, Iwan. (2009). Batik Sebuah Lakon. Jakarta :PT Gaya Favorit Press. 